\title{
The mediating effect of Leaders' Idealized Influence on the Relationship between Leaders' Emotional Intelligence and Intention to Perform among Academics in Malaysian Research Universities: Gender as a Moderator
}

\author{
Gopalan Raman ${ }^{1 *}$, Ng Lee Peng ${ }^{2} \&$ Chen, $\mathrm{I}^{-C h i}{ }^{3}$ \\ ${ }^{1,2}$ Department of Business, University Tunku Abdul Rahman, Malaysia \\ ${ }^{3}$ Department of Marketing, University Tunku Abdul Rahman, Malaysia \\ gopalanr@utar.edu.my
}

DOI: https://doi.org/10.37134/jcit.vol10.1.2020

Cite this paper (APA): Raman, G., Lee Peng, N., \& I-Chi, C. (2020). The Mediating Effect of Leaders' Idealized Influence on the Relationship between Leaders' Emotional Intelligence and Intention to Perform among Academics in Malaysian Research Universities: Gender as a Moderator. Journal of Contemporary Issues and Thought, 10, 1-16. https://doi.org/10.37134/jcit.vol10.1.2020

\begin{abstract}
Academic leaders have a significant task to carry out in higher educational institutions, and for the improvement of academic leaders' responsiveness regarding their emotional intelligence and their influence is essential. This research is intended to examine the academic leaders' emotional intelligence and idealized influence towards subordinates intention to perform and how it moderated by academic leaders' gender. Drawing from attribution theory and social exchange theory, the research hypothesized that leaders' emotional intelligence and subordinate intention to perform will be mediated by leaders' idealized influence. 386 questionnaires samples from five Malaysian public research universities was obtained with partial least squares structural equation modeling used in analyzing the measurements. The findings revealed that academic leaders' emotional intelligence-subordinates intention to perform relationship mediated via academic leaders' idealized influence. In addition, the mediation analysis revealed that academic leaders' idealized influence mediated the leaders' emotional intelligence-subordinates intention to perform when it was modeled with academic leaders' gender as moderated in the structure model.
\end{abstract}

Keywords: Emotional Intelligence; Idealized Influence; Intention to Perform; Academics and Genders

\section{Introduction}

Ministry of Higher Education of Malaysia is at aggressive restructure and encourages the adoption of institutional policies and strategies that optimize their global ranking, especially in the Academic Ranking of World Universities (ARWU), the Times Higher Education World University Rankings and the QS World University Rankings, currently considered the most influential university rankings (Azman \& Kutty, 2016). Only two Malaysian universities were in the THES Asia Ranking in 2019. Universiti Malaya (UM) in the 300s grouping in the THES International Rankings and Universiti Kebangsaan (UKM) is somewhere in the 600s grouping. The other public universities are either declining or staying stationary at very low end of ranking.

Of equal importance, in March 2019, Universitas 21 (U21) release a finding on 50 countries universities ranking by measuring the education budget/resources including grant allocated for research with expected outcomes such as publication, citation, researchers and 
employability among universities leavers. As for resources, Malaysia was at 11th, 12th and 17th places in 2016, 2017 and 2018. In which, Malaysia resources investment higher than many other developed countries, such as Germany, Korea and New Zealand. On the contrary, with regards to universities outcomes, Malaysia has recorded a permanent decrease, which is in the 39th, 42nd and 45th in the same period. The drop in the U21 ranking of Malaysian universities contradicts with the World University Ranking, "QS" and Times Higher Education World University Ranking (THE) rankings indicator. Therefore, the position of Malaysian public research universities does not merely reflect the actual reality of the academician performance as the output mentioned does not correlate with the ranking. In fact, research on the problems and measures of higher education in Malaysia remains elusive (Ghasemy, Hussin, Megat Daud, Nor, Ghavifekr, \& Kenayathulla, 2018; Ibrahim, Sulaiman, Ibrahim, Malek, \& Bausing, 2018). Therefore, with the gap between ranking and performance, as well as research into higher education, remain limited, this research has the intention to tap further antecedents that will be improved the ranking and performance as a whole, ideally through leadership.

\section{Literature review}

The theory of attribution is more suited in inferring the emotions observed in others (Becker, Conroy, Djurdjevic, \& Gross, 2018), in which the attributes made during the observation are more inter-relational rather than interpersonal (Weiner, 2000). Primarily, subordinates perceive leaders act as naive and the ability to apply their own understanding of emotions, cognitions, and actions (Hareli, 2014; Rudolph \& Tscharaktschiew, 2014). On the whole any attributes, whether positive or negative will leave an understanding that the ability or inability of academic leaders in perceiving subordinates emotions as part of the emotional ability of academic leaders. Meanwhile, the essence of social exchange theory is the returns for both parties in it is distort if only one parties cherish the expected (Blau, 1964; Rasoolimanesh, Jaafar, Kock, \& Ramayah, 2015). For subordinates who perceived positively academic leaders idealized influence and will develop a positive idea about the leaders' idealized influence and develop the thoughts towards intention to perform. Subordinates then reciprocate by wanting to perform in an effective manner and with a positive attitude (Cropanzano \& Mitchell, 2005).

\section{Emotional intelligence and intention to perform}

Emotional intelligence is defined as the ability in processing information on the recognition, understanding, and management of emotion in oneself and others (Checa \& FernándezBerrocal, 2019; Muyia \& Kacirek, 2009). Recently, some writers began to research the role of work intentions (Bakker, Schaufeli, Leiter, \& Taris, 2008; Pinder, 2014) but research on intention to perform as a criterion remains elusive. Intention to perform is an intention to execute their job tasks at an elevated level to contribute to the organization's success (Zigarmi, Nimon, Houson, Witt, \& Diehl, 2012). In spite of this, many scholars have agreed that emotional intelligence is vital in leadership and the leader's achievement as well as their performance (Nelson \& Low, 2011; Shuck \& Herd, 2012; Yukl \& Mahsud, 2010). However, the relationships between academic leaders' emotional intelligence and subordinate's intention to perform is still new in academic world. Thus, for the reason above, emotional 
intelligence could possibly affect performance through intention to perform. Thus, this investigation unload its relationship with intention to perform by assessing emotional intelligence. Thus, the following hypothesis is proposed:

Hypothesis 1: Leaders' emotional intelligence positively influence intention to perform among subordinates.

\section{Emotional intelligence and idealized influence}

Dionne, Yammarino, Atwater and Spangler (2004) described idealized influence as leadership concerns with the formulation and articulation of vision, challenging goals and motivating employees to work beyond their self-interest in order to achieve common goals. Puni, Mohammed and Asamoah (2018) and, Zainuddin, Indra and Rizal (2019) mentioned that leaders with idealized influence characteristics are trusted to make good decisions as they have profound emotional connection and command with subordinates. As such, it is strongly believed that leader with idealized influence behaviors in an organization will increased their emotional intelligence abilities towards their subordinates in a reciprocal relationship. To be specific, studies on emotional intelligence and individual components of transformational leadership has been restrained. Ultimately, this research takes the early steps in investigating leaders' emotional intelligence and idealized influence. In light of the discoveries about potential connections among the emotional intelligence and idealized influence, the following hypotheses are detailed.

Hypothesis 2: Leaders' emotional intelligence is positively associated with leaders' idealized influence

\section{Idealized influence and intention to perform}

The relationship between idealized influence and intention to perform can be operationalized by using the key theoretical foundation of social exchange theory in developing the research hypotheses. That is, to create the rationale for formulating the hypotheses, the research utilizes the theory's key theoretical arguments, such an approach has been commonly embraced in research (O'Leary, 2016). Abbas, Iqbal, Waheed and Naveed (2012) cited the important link between idealized influence and employees' positive contribution, meanwhile Hayati, Charkabi and Naami (2014) found that idealized influence has a significantly positive relationship with employee engagement. In addition, Egheosasa, Ugbo and Nkenne (2018) found that idealized influence behaviors significantly affect job satisfaction among employees. Finally, Jerobon, Kimutai and Kibe (2016) found that idealized influence significantly predicts employee performance among employees. As studies on idealized influence towards intention to perform are limited and it is understandable to promote subordinates work performance through intention to perform. Thus, the following hypothesis is proposed:

Hypothesis 3: Leaders' idealized influence is positively related to subordinates intention to perform. 
Since there has been limited studies in idealized influence as mediation construct between emotional intelligence and intention to perform, inference approach can be used in explaining idealized influence as a mediator between emotional intelligence and intention to perform. For instance, various studies examining the effects of emotional intelligence and outcomes can be inferred in explaining the mediation relationship (Sood \& Kaushal, 2018). Therefore, this current research inferred that emotional intelligence can increase positive emotions and improved performance among subordinates by increasing the level of intention to perform in subordinates. On the contrary, evidence towards the intention to perform is still elusive. With inferred approach as suggested, thus, the following hypothesis is proposed:

Hypothesis 4: Leaders' idealized influence will mediate the relationship between leaders' emotional intelligence and intention to perform among academics.

Gender as a moderator

There is thriving proof proposing that by and large women are more emotionally intelligent than men. While females are assumed to be more conducive than males, they do not appear to receive the same appreciation for leadership (Heilman, Wallen, Fuchs, \& Tamkins, 2004; Kulich, Trojanowski, Ryan, Haslam, \& Renneboog, 2011). Meanwhile, Stempel, Rigotti and Mohr (2015) in their research of leaders' leadership, the idealized influence was classified as being gender-neutral. This gap could indicate distinct norms for women and men in assessing their leadership styles (Heilman \& Haynes, 2005). Given these distinctive differences, it is essential to understand how gender has a critical impact on the achievement of an organization. Leading to efforts to address a gap in literature where there is restricted empirical research on the effect of gender on emotional intelligence and idealized influence, thus the following hypothesis is proposed:

Hypothesis 5: Gender will moderate the relationship between emotional intelligence and idealized influence, so that the association will be stronger for female than for male leaders.

\section{Methods}

\section{Participants}

The data was collected from five Malaysian public research universities, Universiti Malaya, Universiti Sains Malaysia, Universiti Kebangsaan Malaysia, Universiti Putra Malaysia and Universiti Teknologi Malaysia. Respondents are all the academicians, namely, department heads, sr lecturers, and lecturers. To generalize the research finding, sample size determination is critical. In this research sample size was resolute by using the guideline from Krejcie and Morgan (1970), and to date the guidelines is accepted thoroughly by social science researchers (Wahab, Shah, \& Faisalmein, 2019). A sample size of 370 was decided and 386 usable questionnaires were collected by the academics out of 750 questionnaires distributed, yielding an overall response rate of almost 51.4 percent. In general, this response rate was moderately higher than response rates of academics in organizational research 
(Fauzi, Tan, Ramayah, \& Adedapo, 2018; Janudin, Maelah, Amir, \& Abdullah, 2015; Farid, Izadi, Ismail, \& Alipour 2015). The sample consisted 386 respondents (Females $=238,61.7 \%$; Males $=148 ; 38.3 \%$ ). Respondents hold various positions, Dean $=0.8 \%$, Deputy Dean $3.1 \%$, Head of department (HOD) 11.4\%, Head of program (HOP) $7.8 \%$ and Non-Administration Holders $76.9 \%$. Most respondents hold permanent employment status (98.7\%). Together with the questionnaire, a cover letter was attached explaining objectives of research and assuring the highest integrity and confidentiality of the data (Kumar, Talib, \& Ramayah, 2013). Quota sampling is a non-probability sampling was used in this research to ensure identified group of male and female academics from five public research universities and the populations are adequately represented. In which, quota sampling, this research pre-specify the control characteristics and choose dispersal in the population (Sarstedt, Bengart, Shaltoni, \& Lehmann, 2017). As the respondent is selected is unknown but the location of respondents is known, convenience sampling was used.

\section{Measurement}

The measurement scales for the emotional intelligence, idealized influence and intention to perform are adapted from various researches and have high reliability and validity in testing the theories. The emotional intelligence scale was adapted from 16 items Wong and Law (2002). The present research was interested in examining idealized influence, therefore, Edwards, Knight, Broome and Flynn (2010) of 19 items were adapted. Finally, the intention to perform measurement by Zigarmi and Roberts (2012) 5 items were adapted.

\section{Data Analysis and Results}

Structural equation modeling (SEM) has become the most popular statistical methods to analyze multivariate data. This research intention was to envisage the affiliation between the construct of emotional intelligence (EI) and intention to perform (ITP), mediated by idealized influence (II) and the emotional intelligence as a construct is formative in nature. The use of PLS-SEM is appropriate in this research as emotional intelligence a reflective-formative higher-order construct. The items in the four components of emotional intelligence, perceiving, using, understanding and regulation are not interchangeable as the scores of the items in each component are expected to uniquely contribute to the underlying construct of emotional intelligence (Jarvis, MacKenzie, \& Podsakoff, 2003).

As this research respondents base on self-reported, therefore common method bias is potential to occur, anyhow this research's measurement for common method bias was at 30.536 percent of total variance and is lower than recommended 50 percent (Podsakoff, MacKenzie, Lee, \& Podsakoff, 2003) as such, common method bias has been overruled in this research. Table 2 indicates the values obtained from the measurement model with all loadings are higher than 0.70 which is the threshold proposed by Hair, Hult, Ringle and Sarstedt (2014). The average variance extracted (AVE) of all contracts surpasses 0.5 (Bagozzi \& Yi, 1988) while the composite reliability score (CR) is higher than 0.7. Thus, we can reason that convergent validity is achieved. The common acceptable threshold for VIF is below 5 (Hair, Sarstedt, Ringle, \& Mena, 2012). Table 3 indicates the VIF value of 3.169 for OEA, 3.094 for ROE, 2.972 of SEL and 3.905 of UOE and meanwhile for the inner VIF value for the second order of emotional intelligence and idealized influence is at 3.408 respectively. 
Therefore, VIF values for first and second order indicating no collinearity problem in this research. Discriminant validity was performed to establish that all the constructs are distinct from each other. Discriminant validity is a problem when HTMT value that is greater than the value of 0.85 (Kline, 2011) or 0.90 (Gold, Malhotra, \& Segar, 2001). Table 4 clearly shown that all constructs were less than 0.85 value as strongly indicated by (Kline, 2011; Franke \& Sarstedt, 2018). Hence, this research indicates discriminant validity presents between all the constructs and most of the items of constructs were not assessing among them.

Table 2: Results of measurement model analysis (Reliability of Constructs)

\begin{tabular}{|c|c|c|c|c|c|}
\hline Items & Loadings & Cronbach's Alpha & rho_A & $\mathrm{CR}$ & AVE \\
\hline II10 & 0.862 & 0.978 & 0.980 & 0.980 & 0.780 \\
\hline II11 & 0.898 & & & & \\
\hline II12 & 0.877 & & & & \\
\hline II13 & 0.899 & & & & \\
\hline II15 & 0.910 & & & & \\
\hline II16 & 0.904 & & & & \\
\hline II17 & 0.898 & & & & \\
\hline II18 & 0.868 & & & & \\
\hline II19 & 0.862 & & & & \\
\hline II5 & 0.830 & 0.978 & 0.979 & 0.983 & 0.919 \\
\hline II6 & 0.886 & & & & \\
\hline II7 & 0.870 & & & & \\
\hline II8 & 0.900 & & & & \\
\hline II9 & 0.897 & & & & \\
\hline ITP1 & 0.940 & & & & \\
\hline ITP2 & 0.980 & & & & \\
\hline ITP3 & 0.975 & & & & \\
\hline ITP4 & 0.934 & & & & \\
\hline ITP5 & 0.963 & & & & \\
\hline OEA1 & 0.836 & 0.941 & 0.953 & 0.958 & 0.852 \\
\hline OEA2 & 0.952 & & & & \\
\hline OEA3 & 0.951 & & & & \\
\hline OEA4 & 0.948 & & & & \\
\hline ROE1 & 0.945 & 0.934 & 0.939 & 0.953 & 0.835 \\
\hline ROE2 & 0.936 & & & & \\
\hline ROE3 & 0.864 & & & & \\
\hline ROE4 & 0.907 & & & & \\
\hline SEL1 & 0.887 & 0.934 & 0.937 & 0.953 & 0.835 \\
\hline SEL2 & 0.922 & & & & \\
\hline SEL3 & 0.939 & & & & \\
\hline SEL4 & 0.908 & & & & \\
\hline UOE1 & 0.935 & 0.939 & 0.942 & 0.957 & 0.846 \\
\hline UOE2 & 0.880 & & & & \\
\hline UOE3 & 0.930 & & & & \\
\hline
\end{tabular}


UOE4

0.933

Note: For reflective scales, the standardized loading is provided; for formative scales, the weight of the linear combination is given. "CR = Composite reliability, AVE = Average Variance Extracted", Items III, II2 II3, II4 and III4 were deleted.

Table 3: Collinearity Assessment, VIF and Outer Weights Values of second-order construct (formative)

\begin{tabular}{|c|c|c|c|c|c|c|c|}
\hline $\begin{array}{l}\text { Second } \\
\text { Construct }\end{array}$ & Order & $\begin{array}{l}\text { First Order } \\
\text { Construct }\end{array}$ & Weights & Measure Type & $\mathrm{t}$-Value & $\mathrm{p}$-value & VIF \\
\hline \multirow{4}{*}{\multicolumn{2}{|c|}{$\begin{array}{l}\text { Emotional } \\
\text { Intelligence }\end{array}$}} & OEA & 0.164 & Formative & 2.830 & 0.002 & 3.169 \\
\hline & & ROE & 0.408 & & 6.192 & 0.000 & 3.094 \\
\hline & & SEL & 0.146 & & 2.632 & 0.004 & 2.972 \\
\hline & & UOE & 0.377 & & 5.300 & 0.000 & 3.905 \\
\hline EI & & & 0.659 & & 11.299 & 0.000 & 3.408 \\
\hline II & & & 0.207 & & 3.498 & 0.000 & 3.408 \\
\hline
\end{tabular}

Table 4: Results of (HTMT) ratio (For First-Order Construct)

\begin{tabular}{|c|c|c|c|c|c|c|}
\hline & II & ITP & OEA & ROE & SEL & UOE \\
\hline \multicolumn{7}{|l|}{ II } \\
\hline \multirow[t]{2}{*}{ ITP } & 0.770 & & & & & \\
\hline & CI.90 $(0.095,0.319)$ & & & & & \\
\hline \multirow[t]{2}{*}{ OEA } & 0.780 & 0.715 & & & & \\
\hline & CI.90 $(0.114,0.387)$ & CI.90 (-0.156,0.094) & & & & \\
\hline \multirow[t]{2}{*}{ ROE } & 0.810 & 0.811 & 0.769 & & & \\
\hline & CI.90 (0.203,0.425) & CI.90 $(0.157,0.414)$ & CI.90 $(0.037,0.308)$ & & & \\
\hline \multirow[t]{2}{*}{ SEL } & 0.734 & 0.745 & 0.812 & 0.765 & & \\
\hline & CI.90 $(-0.027,0.190)$ & CI.90 $(0.038,0.271)$ & CI.90 $(0.238,0.454)$ & CI.90 $(0.116,0.371)$ & & \\
\hline \multirow[t]{2}{*}{ UOE } & 0.814 & 0.823 & 0.828 & 0.850 & 0.814 & \\
\hline & CI.90 $(0.142,0.376)$ & CI.90 (0.184, 0.429) & CI.90 $(0.233,0.549)$ & CI.90 $(0.479,0.723)$ & CI.90 $(0.697,0.813)$ & \\
\hline
\end{tabular}

Note: II = Idealized influence, ITP = Intention to perform, OEA=Others' emotional appraisal, ROE= Regulation of emotion, SEL= Self-emotional of immediate superior's, UOE= Use of emotion

Overall measurement model (emotional intelligence, idealized influence and intention to perform) present research was evaluated. Table 5 demonstrates that the $\mathrm{dG}$ and the dULS are 0.006 and 0.002 respectively. This resonances with a suggestion of a well-fitting measurement model (Dijkstra \& Henseler, 2015). Additionally, the SRMR is 0.01 and NFI is 0.994 . This is below the cut-off of 0.08 and above 0.90 (Hu \& Bentler, 1999) denoting that the measurement model fits in this research.

Table 5: Model Fit

\begin{tabular}{lcc}
\hline & Saturated Model & Estimated Model \\
\hline SRMR & 0.01 & 0.01 \\
d_ULS & 0.002 & 0.002 \\
d_G & 0.006 & 0.006
\end{tabular}




$\begin{array}{ll}\text { Chi-Square } & 12.741 \\ & 0.994 .741\end{array}$

\begin{tabular}{ll} 
NFI & 0.994 \\
\hline
\end{tabular}

The hypothesized conceptual model in this research proposed three direct relationships in total. In table 6 , the path from emotional intelligence to idealized influence was significant ( $\beta$ $=0.841, \mathrm{p}<.001)$. Thus, Hypothesis 1 was supported. Emotional intelligence was significantly related to intention to perform $(\beta=0.659, \mathrm{p}<.001)$, thereby lending support hypothesis 2 . Idealized influence was significantly related to intention to perform $(\beta=.207, \mathrm{p}<.001)$. Thus, Hypothesis 3 was supported. The coefficients path estimates of this structural model are shown in table 6. These results support all three hypothesized relationships/effects (i.e. H1, $\mathrm{H} 2$ and $\mathrm{H} 3$ ) in this research. Meanwhile, $\mathrm{t}$-value for $\mathrm{H} 1, \mathrm{H} 2$ and $\mathrm{H} 3$ are greater than 2.58 $(\mathrm{p}<0.01)$, as such and further supporting that all the three hypotheses are significant, figure 2 .

Next, this research evaluates the effect size (f2) that determines the relative contributions or the strength of the exogenous constructs in producing R2 value for the endogenous construct. Cohen's (1988) guideline was used to determine the magnitudes of the effect size. The magnitudes effects are .02(small), .15(medium), and .35(large). In this research, intention to perform is predicted by emotional intelligence and idealized influence and Table 6 indicates effect sizes (f2) of this research. Emotional intelligence has a large effect in generating the R2 for intention to perform ( $\mathrm{f} 2=0.432$ ) and on idealized influence ( $\mathrm{f} 2=2.408$ ). Meanwhile, effect size between II and ITP is small with $\mathrm{f} 2=0.042$. Notwithstanding the size of R-squared, Chin, Peterson and Brown (2008) mentioned that the predictive sample reuse method (Q2) adequately utilized as a predictive relevance measurement. This research adapted Q2 procedures suggested by Chin (1998), using cross-validated redundancy. Q2 value that is more prominent than 0 implies that the model has prescient significance while Q2 under 0 implies model needs prescient pertinence (Akter et al., 2011). Table 6 indicates predictive relevance $(\mathrm{Q} 2)$ idealized influence and intention to perform are 0.689 and 0.680 respectively indicating acceptable predictive relevance.

Table 6: Hypothesis results

\begin{tabular}{lcccccccccc}
\hline Hypothesis & Beta Value & Std error & t-value & p-value & LL & UL & $\mathbf{R}^{2}$ & $\mathbf{f}^{2}$ & $\mathbf{Q}^{2}$ & Decision \\
\hline EI -> II & 0.841 & 0.014 & $60.244^{* * *}$ & 0.000 & 0.813 & 0.860 & 0.707 & 2.408 & 0.689 & supported \\
EI -> ITP & 0.659 & 0.057 & $11.299^{* * *}$ & 0.000 & 0.553 & 0.746 & 0.705 & 0.432 & 0.680 & supported \\
II -> ITP & 0.207 & 0.058 & $3.498^{* * *}$ & 0.000 & 0.114 & 0.309 & & 0.042 & supported \\
\hline
\end{tabular}

Note: EI= Emotional intelligence, II= Idealized influence, ITP= Intention to perform Significant level ${ }^{*} \mathrm{p}<0.05,{ }^{* *} \mathrm{p}<0.01{ }^{* * *}$, $\mathrm{p}<0.001$

Meanwhile, R-square $\left(\mathrm{R}^{2}\right)$ value interprets the proportion of dependent variable variance that is explained by the independent variable. R-square infers the coefficient for determination in criterion constructs. Hair et al., (2017) conclude the R-square strength of 0.75 is strong, moderate for 0.5 , and at the weaker side is 0.25 . Figure 1 indicates the R-square value of emotional intelligence is 0.705 . This shows that 70.5 percent of intention to perform variance can be explained by emotional intelligence and idealized influence. Meanwhile, R- square value of idealized influence is 0.707, indicating strong R-square, in which 70.7 percent variance in idealized influence is explained by emotional intelligence. Therefore, another 29.5 percent of other variables are not being explained on the intention to perform and similarly 29.3 percent of variables are not explainable on idealized influence. 


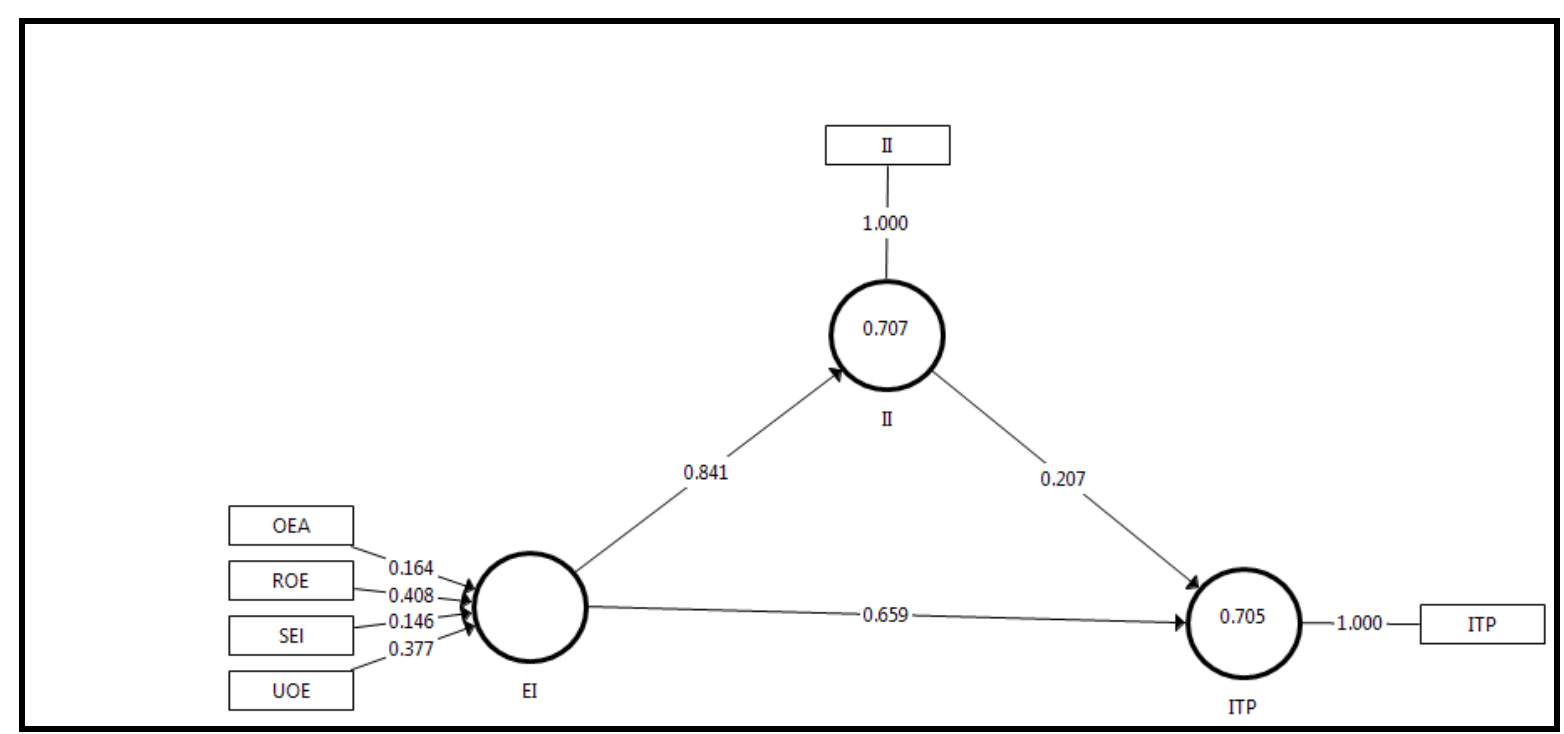

Figure 1. Second order Measurement Model

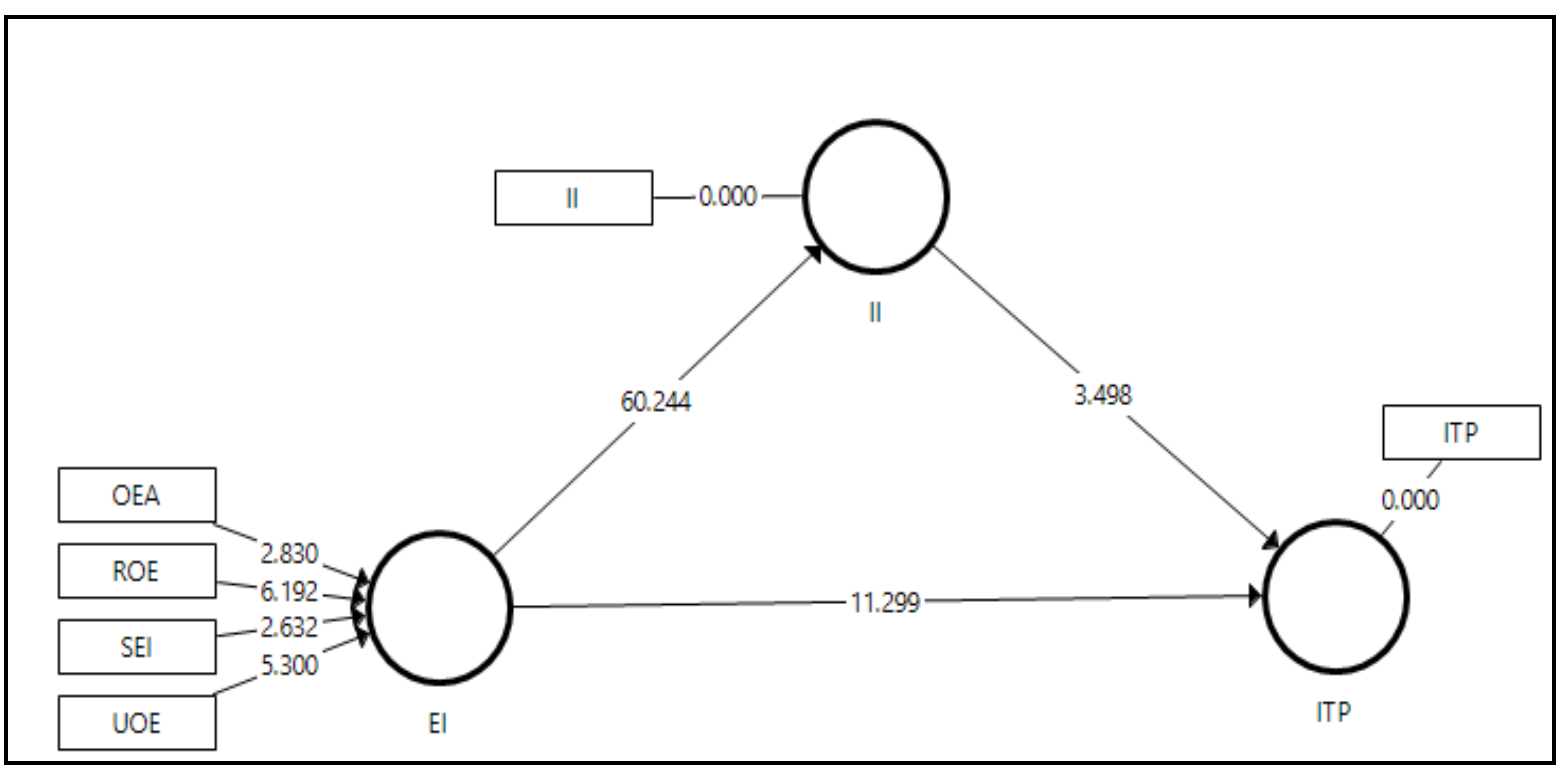

Figure 2. Structural Model

Table 7: Mediating effect of idealized influence

\begin{tabular}{lccccccc}
\hline Hypothesis & Beta Value & Std Error & t-value & p-value & LL & UL & Decision \\
\hline EI $->$ II $->$ ITP & 0.174 & 0.050 & $3.505^{* * *}$ & 0.000 & 0.1 & 0.261 & Supported \\
\hline
\end{tabular}

Note: EI: Emotional intelligence, ITP $=$ Intention to perform Significant level ${ }^{*} \mathrm{p}<0.05,{ }^{* *} \mathrm{p}<0.01{ }^{* * *}$, $\mathrm{p}<0.001$

Results of the bootstrapping procedure are provided in Table 7 for the test of mediation hypotheses. Preacher and Hayes (2008) explained that indirect effects should not straddle a 0 to indicate mediation. As for the mediating role of idealized influence in the emotional intelligence-intention to perform relationship, it is evident from the results that the relationship "confidence interval" does not contain zero $[.01, .261]$ and therefore it is significant $(\beta=0.174, p=0.0001)$. This result lends support to Hypothesis H4. 
Table 8: Moderating effect

\begin{tabular}{lccccccc}
\hline Hypothesis & Beta & Th & T Value & LL & UL & Decision \\
\hline EI $x$ Gender $->$ II & 0.103 & 0.025 & $4.072^{* * *}$ & 0.000 & 0.061 & 0.145 & Supported \\
\hline
\end{tabular}

Significant level ${ }^{*} \mathrm{p}<0.05,{ }^{* *} \mathrm{p}<0.01^{* * *} \mathrm{p}<0.001$

Note: EI= Emotional intelligence, $\mathrm{II}=$ Idealized influence

Table 8 shows that there is significant interaction effect $(\beta=0.103, p$-value $=0.000)$. This shows that gender moderates the relationship between emotional intelligence and idealized influence. The analysis of moderation plot is performed by interpreting the slopes gradient. Figure 3, academic leaders' gender is represented by both lines, female academic leader emotional intelligence green line (top) is slightly higher slopes related to male blue (bottom) academic leaders' emotional intelligence. This suggests that the affiliation between "emotional intelligence and idealized influence" is higher among female academic leaders compare to male academic leaders.



Figure 3. Moderation

\section{Discussion of Findings}

The outcomes from the partial least square analysis significantly indicating a positive link between academic leaders' emotional intelligence and subordinates intention to perform, which supports hypothesis 1 in this research. These outcomes corroborate the pertinent role of attribution theory that individual will interpret a meaning of why people behaving in that manner and comprehend the attribute of one or more cause to that act (Heider, 1958; Jones, 1973). In addition, attribution theory is able to infer emotions in others (Becker, Conroy, Djurdjevic, \& Gross, 2018). Thus, attribution process begins with observing academic leaders' emotional intelligence abilities by subordinate and reflecting positive or negative perceptions towards their leaders' emotional intelligence.

Meanwhile, outcomes from PLS analysis revealed that academic leaders' emotional intelligence positively linked to idealized influence among academic leaders. The finding is supported by the leaders' universal norms of responsive and responsible leadership as 
mentioned by Kim and Kim (2017). It is been acknowledge that leaders also weight the same emotions as subordinates going through, in which subordinates perceived that their emotions are being noticed by their leaders. Thus, this research indicates that when subordinates form positive perceptions in their academic leaders as a result of positive benevolent treatment from their academic leaders. Subsequently, it serves as a stronger and more sufficient indication for the subordinates to perceived strong idealized influence in academic leaders. Hence, this current research inferred that conceptualization of idealized influence is reflective in emotional intelligence conceptualization as both portray leaders' emotional intelligence has idealized influence characters.

Hypothesis 3 proposed that idealized influence is positively correlated to the intention to perform. Brown and Treviño (2009) mentioned that leaders' behaviors related with idealized influence will enhance subordinates' perceptions, as subordinates reflect their own beliefs and principals in their leader (Brown \& Treviño, 2009). In sum, this research indicates academic leaders' idealized influence to positively influence subordinates perceptions, because these academic leaders make prominent understanding that their subordinates' aspiration and values can align with their own and eventually meeting the organizations' goals (Jiang, Lepak, Hu, \& Baer, 2012; Kristof-Brown, Zimmerman, \& Johnson, 2005).

According to social exchange theory, the level of expectation of future returns by an individual is a discretion need to be looked upon by leaders, as this behavior is part of reciprocal relationship (Blau, 1964). Therefore, the relationship between idealized influence and intention to perform can be explained by social exchange theory (Blau 1964), which is engrained in the reciprocal relations (Gouldner, 1960; Perugini, Gallucci, Presaghi, \& Ercolani, 2003). Thus, centered on social exchange theory (Blau, 1964) and the principles of exchange (Gouldner, 1960), academic leaders' idealized influence motivates subordinates to reciprocate favours through physical, emotional, and cognitive engagement towards intention to perform. This research can conclude that academic leaders' emotional intelligence can infiltrate subordinates' norms, belief and expectancies through academic leaders' idealized influence.

Finally, hypothesis 5 predicted that a leader's gender would moderates the relationship between leaders' emotional intelligence and leaders' idealized influence. The findings of this research conclude the academic female leaders in Malaysian public research universities has the ability in managing emotions and leading academic intention to perform. Thus, female leaders who demonstrate higher emotional intelligence has greater ability in influencing the subordinates as compared to male leaders. This is because academic female leaders and male leaders have different perceptions of valuation and interpretation due to leaders' gender segmentation. Therefore, this research further infers the consistency in the findings that female academic leaders high in emotional intelligence will effectively influence the subordinates' intention with their idealized influence.

\section{Theoretical contributions and implications}

The theoretical contribution and theoretical implications of the research are now discussed. Attribution theory suggests specific antecedents affect the perceptions of a person towards an event and influence his/her intentions and outcomes. These underlying inductions 
alluded to attribution. Importantly, this attribution has an affective or emotional response in it (Snead, Magal, Christensen, \& Ndede-Amadi, 2015). Outlining from social exchange theory, this research viewed academic leaders idealized influence relationship which suggests that benevolent acts of one party towards the other party make the other party feel influence to reciprocate in kind, thus, motivating the other party to display attitudes and behaviors that are sufficient to discharge those influence and trust (Judge \& Piccolo, 2004). Thus, social exchange theory provides explanation within the academic leaders' idealized influence and their subordinate's intention to perform. In addition to contributing theoretically to the subordinate's intention to perform literature, the research also has an important theoretical implication.

\section{Practical implications}

Human resource perspective, selection methods of hiring new academic leaders or appointing academic leaders can serve the first initiative to instill leaders' emotional intelligence in public research universities. It has been noted that most of the public universities have their leaders especially dean or head of department in a rotation basis and there is also in some cases the dean or head of departments are hired from different higher institution. Nevertheless, regardless of internal rotations or external hiring, this research strongly suggesting the fine-tuning of the selection process via effective interviews. Notably, to predict performance a cognitive test can be used to measure general intelligence (Klotz et al., 2013; Schmidt \& Hunter, 1998; Van Iddekinge \& Ployhart, 2008) as proxies to test perception component of emotional intelligence in leaders. Meanwhile, personality tests determine a leader's personality and agreeableness is one such personality trait that defines trustfulness, cooperation, friendliness, and compliance (Barrick, Mount, \& Judge, 2001; Georgellis \& Sankae, 2016). Trustworthiness and agreeableness are a proxy for the benevolence component of idealized influence (Klotz et al., 2013; Schmidt \& Hunter, 1998).

Emotional intelligence is to be related to the emotional stability dimension especially in regulation of emotions and utilization of emotions (Ehring, Tuschen-Caffier, Schnülle, Fischer, \&Gross, 2010; Webb, Miles, \& Sheeran, 2012). As such, emotional stability is another test that can be conducted in evaluating academic leaders' emotional intelligence Training is another approach that public research universities can enhance emotional intelligence abilities and idealized influence characteristics of their leaders. In addition, as the findings suggest, female academic leader's emotional intelligence abilities are higher than male academic leaders, therefore male academic leaders should enhance their leadership by cultivating the communal attributes.

Therefore, this research in the leadership context, suggests that emotional intelligence should earn revived consideration in the human talent advancement and an extreme determinant of successful leadership in the new period of education 4.0. Truth be told, it may be the ideal opportunity for leadership via human resources to explore education 4.0 has to suggest over the different elements of the field of knowledge and new offerings. Things are evolving significantly, thus too, human talent and development.

\section{Research limitations and suggestions for future research}


Cross-sectional design was implored, Experts caution that cross-sectional data raise concerns about the internal validity of the findings, because as mentioned by Shadish, Cook and Campbell (2002) such data make it difficult for the researcher to determine the direction of causality among variables with absolute certainty. Therefore, there remains a possibility of inverse causality effects in the cross-sectional data that provides room for alternative explanations of the phenomenon under investigation. The positive antithesis scholars have not measured intention to perform from this perspective in many longitudinal studies over the course of a single day or week, as mentioned by Shevlin and Rose (2017) that longitudinal research will gain insights into how inclusion is conceptualized and "what type of inclusive practice" is available in research.

Self-reports were used to collect data in this research and may contribute to common method bias. Podsakoff et al. (2003) mentioned that biasness happened when false "covariance" between the predictor and criterion variable exist because respondents' consistency motif and moods in respondents. Anyhow, Spector (2006) believes that the selfreport method is the most reliable method to get accurate information about the internal states of employees, and not all constructs are always prone to common method bias

The theory proposed in this research was tested on academics from five public research higher institutions in Malaysia. Therefore, the findings of this research may not generalize to other public and private universities, or samples belonging to different occupational groups. Future research should replicate this research on academics of both private and public universities in Malaysia by gathering multiple waves of data across different times. The research measured the phenomenon of intention to perform from a single source by asking the subordinates directly. Future research should measure intention to perform from sources other than the same respondents.

\section{Conclusion}

One of the effective factors for higher institutions to achieve excellence is the leadership style of their academic leaders. The findings in this research conclude that emotional intelligence is a key predictor in leadership styles particularly with idealized influence and towards intention to perform. The outcomes indicated a significant and direct relationship between academic leaders' emotional intelligence and intention to perform as perceived by the subordinates.

\section{Acknowledgment}

This work was supported by University Tunku Abdul Rahman Research Fund (UTARRF) grant funded by University Tunku Abdul Rahman (No: 6200/G43).

\section{REFERENCES}

Abbas, G., Iqbal, J., Waheed, A., \& Naveed Riaz, M. (2012). Relationship between Transformational Leadership Style and Innovative Work Behavior in Educational Institutions. Journal of Behavioural Sciences, 22(3), 18-32.

Akter, S., D'Ambra, J. \& Ray, P. (2011). Trustworthiness in mHealth information services: an assessment of a hierarchical model with mediating and moderating effects using partial least squares (PLS). Journal of the American Society for Information Science and Technology, 62(1), 100-116. 
Azman, N., \& Kutty, F.M. (2016). Imposing global university rankings on local academic culture. In M. Yudkevich, P.G. Altbach, \& L.E. Rumbley (Eds.), The global academic rankings game: Changing institutional policy, practice, and academic life (pp. 97-123). New York, NY: Routledge.

Bagozzi, R.P., \& Yi, Y. (1988). On the evaluation of structural equation models. Journal of the academy of marketing science, 16(1), 74-94.

Barrick, M.R., Mount, M.K., \& Judge, T.A. (2001). Personality and performance at the beginning of the new millennium: what do we know and where do we go next? International Journal of Selection and Assessment, 9(1-2), 9-30.

Becker, W., Conroy, S., Djurdjevic, E., \& Gross, M. (2018). Crying is in the eyes of the beholder: An attribution theory framework of crying at work. Emotion Review, 10(2), 125-137.

Blau, P.M. (1964). Justice in social exchange. Sociological Inquiry, 34(2), 193-206.

Brown, M.E., \& Treviño, L.K. (2009). Leader-follower value congruence: Are socialized charismatic leaders better able to achieve it? Journal of Applied Psychology, 94(2), 478-490.

Checa, P., \& Fernández-Berrocal, P. (2019). Cognitive control and emotional intelligence: Effect of the emotional content of the task. Brief Reports. Frontiers in Psychology, 10, 1-4.

Chin, W.W. (1998). The partial least squares approach to structural equation modeling. Modern methods for business research, 295(2), 295-336.

Chin, W.W., Peterson, R. A., \& Brown, S. P. (2008). Structural equation modeling in marketing: Some practical reminders. Journal of marketing theory and practice, 16(4), 287-298.

Cohen, S. (1988). Psychosocial models of the role of social support in the etiology of physical disease. Health psychology, 7(3), 269-297.

Cropanzano, R., \& Mitchell, M.S. (2005). Social exchange theory: An interdisciplinary review. Journal of Management, 31(6), 874-900.

Dionne, S.D., Yammarino, F.J., Atwater, L.E., \& Spangler, W.D. (2004). Transformational leadership and team performance. Journal of organizational change management, 17(2), 177-193.

Dijkstra, T.K., \& Henseler, J. (2015). Consistent and asymptotically normal PLS estimators for linear structural equations. Computational Statistics \& Data Analysis, 81(1), 10-23. doi:10.1016/j.csda.2014.07.008

Edwards, J.R., Knight, D.K., Broome, K.M., \& Flynn, P.M. (2010). The development and validation of a transformational leadership survey for substance use treatment programs. Substance Use \& Misuse, 45(9), 1279-1302.

Egheosasa, D.O.O., Ugbo, P.O. \& Nkenne, C.O. (2018). Effects of Transformational Leadership Style on Job Satisfaction Among Employees of Bosso and Minna Area Offices of Abuja Electricity Distribution Company PLC Nigeria. International Journal of Social Sciences and Humanities Review, 8(2), 161173.

Ehring, T., Tuschen-Caffier, B., Schnülle, J., Fischer, S., \& Gross, J.J. (2010). Emotion regulation and vulnerability to depression: Spontaneous versus instructed use of emotion suppression and reappraisal. Emotion, 10(4), 563-572.

Farid, H., Izadi, Z., Ismail, I.A., Alipour, F. (2015). Relationship between quality of work life and organizational commitment among lecturers in a Malaysian public research university. The Social Science Journal, 52(3), 54-61.

Fauzi, M.A., Tan, C.N., Ramayah, T., \& Adedapo, O.O. (2018). An integrative model of knowledge sharing in Malaysian higher learning institute. Kybernetes, 47(5), 1031-1052.

Franke, G., \& Sarstedt, M. (2019). Heuristics versus statistics in discriminant validity testing: a comparison of four procedures. Internet Research, 29(3), 430-447.

Georgellis, Y., \& Sankae, N. (2016). The personality of managers in Britain: Gender and sector difference. Evidence-based HRM: A Global Forum for Empirical Scholarship, 4(1), 67-80.

Ghasemy, M., Hussin, S., Megat Daud, A.K.M., Nor, M.M., Ghavifekr, S., \& Kenayathulla, H.B. (2018). Issues in Malaysian higher education: a quantitative representation of the top five priorities, values, challenges, and solutions from the viewpoints of academic leaders. SAGE Open, 8(1), 1-15.

Gold, A.H., Malhotra, A., \& Segars, A.H. (2001). Knowledge management: An organizational capabilities perspective. Journal of Management Information Systems, 18(1), 185-214.

Gouldner, A. W. (1960). The norm of reciprocity: A preliminary statement. American Sociological Review, 25(2), 161-178.

Hair, J.F., Hult, G.T.M., Ringle, C.M., \& Sarstedt, M. (2014). A primer on partial least squares structural equation modeling (PLS-SEM). Thousand Oaks: SAGE Publications.

Hair J.F., Hult, G.T.M., Ringle, C.M., \& Sarstedt, M. (2017). A primer on partial least squares structural equation modeling (PLS-SEM) (2nd ed.). Thousand Oaks, CA: Sage Publications

Hair, J.F., Sarstedt, M., Ringle, C.M., \& Mena, J.A. (2012). An assessment of the use of partial least squares structural equation modeling in marketing research. Journal of the Academy of Marketing Science, 40(3), 414-433. 
Hareli, S. (2014). Making sense of the social world and influencing it by using a naïve attribution theory of emotions. Emotion Review, 6(4), 336-343.

Hayati, D., Charkhabi, M., \& Naami, A. (2014). The relationship between transformational leadership and work engagement in governmental hospitals nurses: a survey study. Springerplus, 3(1), 1-7.

Heider, F. (1958). The Psychology of interpersonal relations. New Jersey, USA: Lawrence Erlbaum Associates Inc.

Heilman, M.E., \& Haynes, M.C. (2005). No credit where credit is due: attributional rationalization of women's success in male-female teams. Journal of Applied Psychology, 90(5), 905-916.

Heilman, M.E., Wallen, A.S., Fuchs, D., \& Tamkins, M.M. (2004). Penalties for success: Reactions to women who succeed at male gender-typed tasks. Journal of Applied Psychology, 89(3), 416-427.

Hu, L.T., \& Bentler, P.M. (1999). Cutoff criteria for fit indexes in covariance structure analysis: conventional criteria versus new alternatives. Structural Equation Modeling, 6(1), 1-55.

Ibrahim, M.A., Sulaiman, W.S.W., Ibrahim, N.I., Malek, M.A.A., \& Bausing, A. (2018). Influence of organizational justice, job satisfaction, organizational commitment, and task performance towards organizational citizenship behavior among academicians. Jurnal Psikologi Malaysia, 32(4), 75-87. Retrieved from http:// spaj.ukm.my/ppppm/jpm/article/download/436/358

Janudin, S.E., Maelah, R., Amir, A.M., \& Abdullah, N.L. (2015). Performance management system and lecturers' performance: Testing the mediation role of competency in Malaysian research universities. International Business Education Journal, 8(1), 105-120.

Jarvis, C.B., MacKenzie, S.B., \& Podsakoff, P.M. (2003). A critical review of construct indicators and measurement model misspecification in marketing and consumer research. Journal of Consumer Research, 30(2), 199-218.

Jerobon, T., Kimutai, G., \& Kibet, Y. (2016). Evaluation of Effects of Transformational Leadership and Employee Performance a Survey of Nandi County Government. Journal of Business and Management, 18(11), 91-101.

Jiang, K., Lepak, D.P., Hu, J., \& Baer, J.C. (2012). How does human resource management influence organizational outcomes? A meta-analytic investigation of mediating mechanisms. Academy of Management Journal, 55(6), 1264-1294.

Jones, S.C. (1973). Self-and interpersonal evaluations: Esteem theories versus consistency theories. Psychological Bulletin, 79(3), 185-201.

Judge, T.A. \& Piccolo, R.F. (2004). Transformational and transactional leadership: a meta-analytic test of their relative validity. Journal of Applied Psychology, 89(5), 755.

Kim, H., \& Kim, T. (2017). Emotional intelligence and transformational leadership: A review of empirical studies. Human Resource Development Review, 16(4), 377-393.

Kline, R.B. (2011). Principles and practices of structural equation modelling. New York, NY: Guilford Press.

Klotz, A.C., da Motta Veiga, S.P., Buckley, M.R., \& Gavin, M.B. (2013). The role of trustworthiness in recruitment and selection: A review and guide for future research. Journal of Organizational Behavior, 34(S1), S104-S119.

Krejcie, R.V., \& Morgan, D.W. (1970). Determining sample size for research activities. Educational and Psychological Measurement, 30(3), 607-610.

Kristof-brown, A.L., Zimmerman, R.D., \& Johnson, E.C. (2005). Consequences of individuals' fit at work: A meta-analysis of person-job, person-organization, person-group, and person-supervisor fit. Personnel Psychology, 58(2), 281-342.

Kulich, C., Trojanowski, G., Ryan, M.K., Haslam, S.A., \& Renneboog, L.D. (2011). Who gets the carrot and who gets the stick? Evidence of gender disparities in executive remuneration. Strategic Management Journal, 32(3), 301-321.

Kumar, M., Talib, S.A., \& Ramayah, T. (2013). Business research methods. Kuala Lumpur, Malaysia: Oxford Fajar/Oxford University Press.

Ministry of Education. (2015). Malaysia Education Blueprint (Higher Education 2015-2025). Putrajaya: Ministry of Education.

Ministry of Higher Education. (2016a). The list of Malaysia's public universities. Retrieved from http://www.mohe.gov.my/ms/institusi/universiti-awam

Ministry of Higher Education. (2016b). Category of public universities. Retreived from http:// www.mohe.gov.my/ms/institusi/universiti-awam/kategori-ua

Nelson, D.B., \& Low, G.R. (2011). Emotional intelligence (2 ${ }^{\text {nd }}$ ed.). Boston: Prentice Hall.

O'Leary, D.E. (2016). Modeling retweeting behavior as a game: Comparison to empirical results. International Journal of Human-Computer Studies, 88, 1-12.

Perugini, M., Gallucci, M., Presaghi, F., \& Ercolani, A. P. (2003). The personal norm of reciprocity. European Journal of Personality, 17(4), 251-283. 
Podsakoff, P.M., MacKenzie, S.B., Lee, J., \& Podsakoff, N.P. (2003). Common methods biases in behavioral research: a critical review of the literature and recommended remedies. Journal of Applied Psychology, 88(5), 879-903.

Preacher, K.J., \& Hayes, A.F. (2008). Asymptotic and resampling strategies for assessing and comparing indirect effects in multiple mediator models. Behavior research methods, 40(3), 879-891.

Puni, A., Mohammed, I., \& Asamoah, E. (2018). Transformational leadership and job satisfaction: the moderating effect of contingent reward. Leadership \& Organization Development Journal, 39(4), 522537.

Rasoolimanesh, S.M., Jaafar, M., Kock, N., \& Ramayah, T. (2015). A revised framework of social exchange theory to investigate the factors influencing residents' perceptions. Tourism Management Perspectives, $16,335-345$.

Rudolph, U., \& Tscharaktschiew, N. (2014). An attributional analysis of moral emotions: Naïve scientists and everyday judges. Emotion Review, 6(4), 344-352.

Sarstedt, M., Bengart, P., Shaltoni, A.M., \& Lehmann, S. (2017). The use of sampling methods in advertising research: A gap between theory and practice. International Journal of Advertising, 37(4), 650-663.

Schmidt, F.L., \& Hunter, J.E. (1998). The validity and utility of selection methods in personnel psychology: Practical and theoretical implications of 85 years of research findings. Psychological Bulletin, 124(2), 262-274.

Shadish, W.R., Cook, T.D., \& Campbell, D.T. (2002). Experimental and quasi-experimental designs for generalized causal inference. Boston, MA, US: Houghton, Mifflin and Company.

Shevlin, M., \& Rose, R. (2017). Leadership approaches to inclusive education: learning from an Irish longitudinal research. In M. Milton (Ed.), Inclusive Principles and Practices in Literacy Education (pp. 53-67). Bingley: Emerald Publishing.

Shuck, B., \& Herd, A.M. (2012). Employee engagement and leadership: Exploring the convergence of two frameworks and implications for leadership development in HRD. Human Resource Development Review, 11(2), 156-181.

Snead, K.C., Magal, S.R., Christensen, L.F., \& Ndede-Amadi, A.A. (2015). Attribution theory: a theoretical framework for understanding information systems success. Systemic Practice and Action Research, 28(3), 273-288.

Sood, I., \& Kaushal, S.L. (2018). Emotional intelligence and leadership styles: A research of educational leaders in Himachal Pradesh. Asian Journal of Management, 9(1), 419-426.

Spector, P.E. (2006). Method variance in organizational research. Organizational Research Methods, 9(2), 221232.

Stempel, C.R., Rigotti, T., \& Mohr, G. (2015). Think transformational leadership-Think female? Leadership, 11(3), 259-280.

UNIVERSITAS. (2018). U21 ranking of national higher education systems 2018 released. https:/universitas21.com/news-and-events/news/u21-ranking-national-higher-education-systems-2018released

Van Iddekinge, C.H., \& Ployhart, R.E. (2008). Developments in the criterion-related validation of selection procedures: A critical review and recommendations for practice. Personnel Psychology, 61(4), 871-925.

Wahab S., Shah M.F.M., \& Faisalmein S.N. (2019). The relationship between management competencies and internal marketing knowledge towards internal marketing performance.

Walters, T. M. (2018). The relationship between emotional intelligence and career intentions of first-year college students at historically black institutions in the southeast (Doctoral's dissertation). Benedictine University, Illinois, USA.

Webb, T.L., Miles, E., \& Sheeran, P. (2012). Dealing with feeling: A meta-analysis of the effectiveness of strategies derived from the process model of emotion regulation. Psychological Bulletin, 138(4), 775808.

Weiner, B. (2000). Intrapersonal and interpersonal theories of motivation from an attributional perspective. Educational Psychology Review, 12(1), 1-14.

Wong, C., \& Law, K.S. (2002). The effects of leader and follower emotional intelligence on performance and attitude: An exploratory research. Leadership Quarterly, 13(3), 243-274.

Yukl, G.A., \& Mahsud, R. (2010). Why flexible and adaptive leadership is essential. Consulting Psychology Journal: Practice and Research, 62(2), 81-93.

Zainuddin, H. D., Indra, P., \& Rizal, S. I. (2019). Implementation of transformational leadership of research program chairperson and its impact on lecturers achievement motivation. Paper presented at the $1^{\text {st }}$ International Conference on Education and Social Science Research (ICESRE 2018).

Zigarmi, D., \& Roberts, T. P. (2012). Leader values as predictors of employee affect and work passion intentions. Journal of Modern Economy and Management, 1(1), 1-28. 